Volver a vivir

Germán Bonnani

Question/Cuestión, Nro.70, Vol.3, diciembre 2021

ISSN: 1669-6581

URL de la Revista: https://perio.unlp.edu.ar/ojs/index.php/question/

IICom -FPyCS -UNLP

DOI: https//doi.org/10.24215/16696581e601

\title{
Volver a vivir
}

Germán Bonnani

Ex soldado combatiente en Malvinas - CECIM La Plata

Argentina

germanbonanni@hotmail.com

Un libro puede contener ideas, sueños, utopías, datos. También puede contener un pedazo de nuestra vida.

Es el caso de Malvinas, viaje al pasado Miguel Savage nos cuenta con muchos detalles, una parte de su vida que seguramente lo ha marcado hasta lo más profundo. Las vivencias de una guerra son en sí mismas, el recuerdo de lo que no queremos que nos pase jamás. Y volcarlas en un libro es como sellarlas de por vida en nuestro más profundo sueño. 
Leer el libro de Miguel, nos transporta a aquellos años y la experiencia de un pibe de 19 años. Cuenta desde el día a la noche de esos interminables 2 meses. Nos narra como se subsistía al hambre, al frío, al miedo.

Muy fácil transportarse y entrar en el libro, sintiéndose cerca del autor.

La subsistencia, lo que lo hacía fuerte, la necesidad de sentirse en casa protegido, hasta ese olor a familia que muy bien describe en la anécdota del pullover azul.

Para los que compartimos con él esos días, la narración meticulosa nos produce sin dudas un volver a vivir esos momentos.

Para los que tuvieron la suerte de no estar ahí, es un libro que muy fácilmente los va llevar a entender lo que Miguel y muchos otros compañeros sintieron, casi como un cuento, y con muchas situaciones desconocidas para muchos.

194 páginas de apasionante lectura, fotos y datos que recuerdan esos días.

Un libro muy recomendable.

Autor: Miguel Savage 
Question/Cuestión, Vol. 3, N 70

Diciembre 2021

ISSN 1669-6581

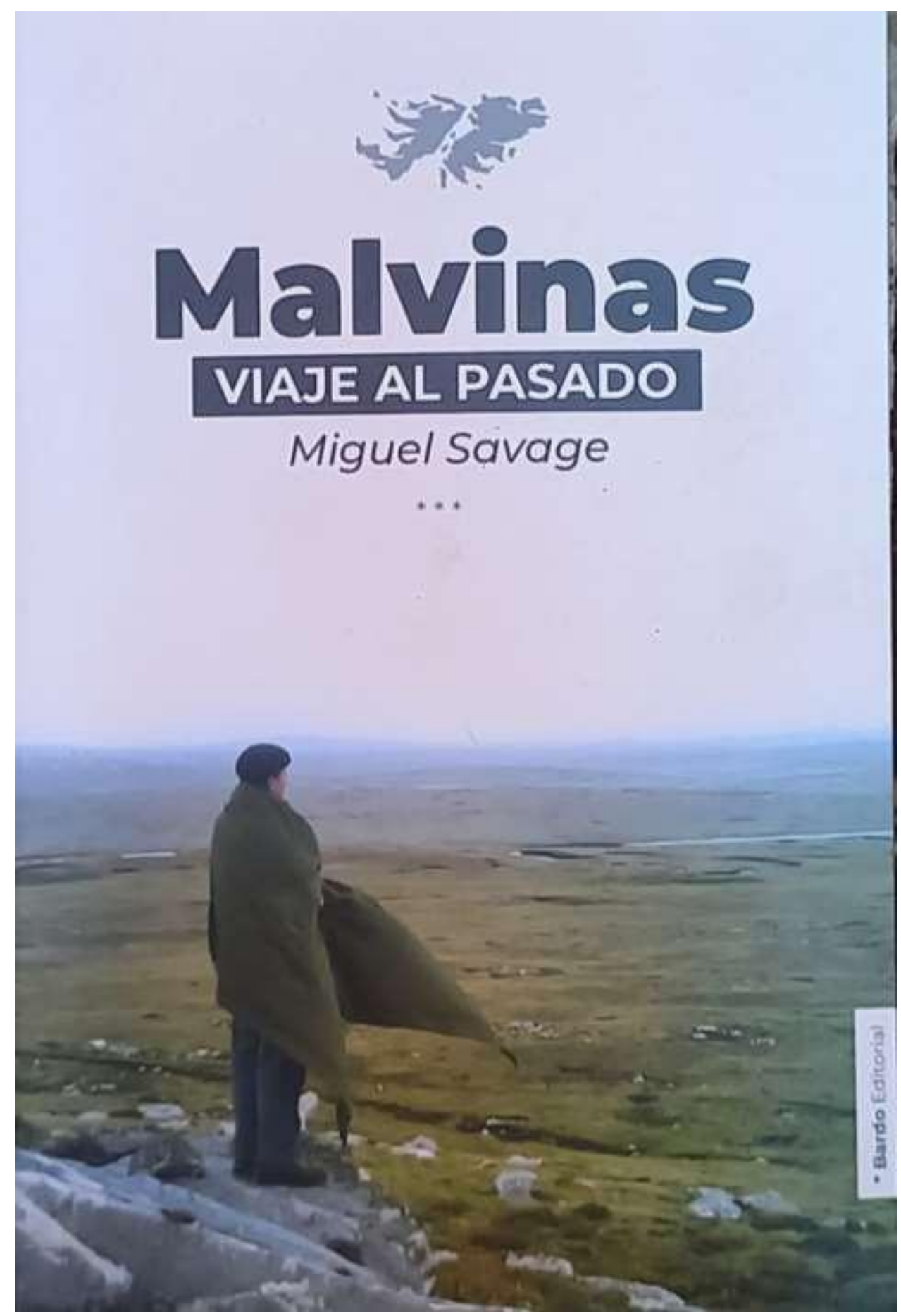

IICom (Instituto de Investigaciones en Comunicación)

Facultad de Periodismo y Comunicación Social

Universidad Nacional de La Plata 
"Soy un sobreviviente de la guerra de Malvinas. Viajé tres veces a las islas para poner los fantasmas a descansar. En uno de esos viajes, devolví un pulóver azul que habia tomado de una estancia para sobrevivir. Durante 20 años no hablé del tema. Una pesadilla en el 2001 fue el comienzo de un alucinante camino sanador, que significó poner en palabras el horror.

Creo que hay tres formas de enfrentar situaciones de gran sufrimiento: tapar todo, victimizarse o abrazar la herida y transformarla en algo positivo. Es por eso que narro con entusiasmo mi historia de vida, compartiendo los aprendizajes y la resiliencia".
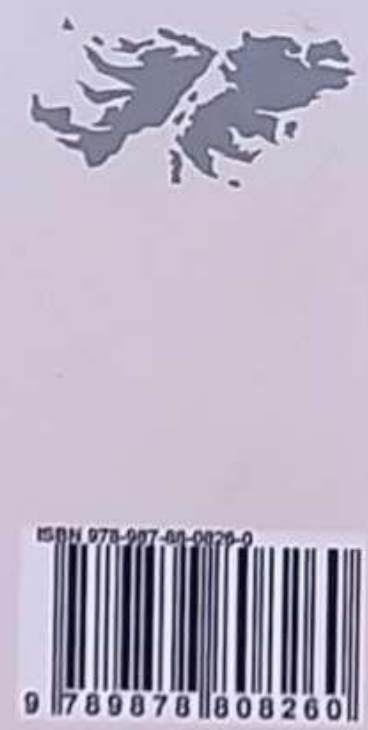